EESTI NSV TEADUSTE AKADEEMIA TOIMETISED. XVII KOIDE KEEMIA * GEOLOOGIA. 1968, Nr. 4

ИЗВЕСТИЯ АКАДЕМИИ НАУК ЭСТОНСКОЙ ССР. ТОМ ХVII Химия - ГЕология. 1968, № 4

К. ЛЭЭТС, Т. КААЛ, Х. ЮРЬЕНС

\title{
О СОСТАВЕ МОНОТЕРПЕНОВЫХ ХЛОРИДОВ ПРОДУКТА ТЕЛОМЕРИЗАЦИИ ИЗОПРЕНА С ЕГО ГИДРОХЛОРИДАМИ
}

\author{
K. LAATSS, T. KAAL, H. JURJENS. ISOPREENI JA TEMA HUDROKLORIIDIDE TELOMERISATSI- \\ OONIPRODUKTI MONOTERPEENKLORIIDIDE KOOSTISEST
}

K. LAATS, $T$, KAAL, H. JURJENS. ON THE COMPOSITION OF THE MONOTERPENIC CHLORIDES OF THE ISOPRENE AND ITS HYDROCHLORIDES TELOMERIZATION PRODUCT

Ранее показано ['], что смесь терпеновых хлоридов, получаемая теломеризацией изопрена с его гидрохлоридами, состоит из геранилхлорида $(52-56 \%), \quad \alpha$-терпинилхлорида $(18-20 \%)$ и меньших количеств (по $7-10 \%)$ линалилхлорида, лавандулилхлорида и дигидрохлорида терпена. Нами доказано наличие во фракции терпеновых хлоридов с т. кип. $60-65^{\circ}$ (4 мм рт. ст.) 3-хлор-2,7-диметил-октадиена-1,6. Омылением соответствующей фракции хлоридов получена смесь двух изомерных спиртов - 2,7-диметилоктадиен-1,6-ола-3 и 2,7-диметилоктадиен2,6 -ола-1 $(1: 1)$, которые выделены с помощью препаративной газовой хроматографии и идентифицированы по спектрам ЯМР $[2,3]$.

Для дигидрохлорида терпена также был снят спектр ЯМР, судя по которому из двух возможных структур 2-хлор-3-хлорметил-2,6-диметилгептена-5 и 6,7-дихлор-2,5,5-триметилгептена-5 наиболее вероятной является первая. Все четыре группы $\mathrm{CH}_{3}$ дают сигнал 1,63 м. д., вероятно, из-за одинакового влияния двойной связи и атома хлора. В случае же второй структуры сигнал двух метильных групп у 5-го углеродного атома должен был бы иметь величину около $1,1-1,2$ м. д., поскольку хлор связан с другим атомом углерода.

ЛИТЕРАТ У РА

1. Лээ т с К. В., ЖОХ, 28, 3096 (1958).

2. Эрм А., Л ээтс К., Изв. АН ЭССР, Хим. Геол., 16, № 1, 37 (1967).

3. Лээтс К., Эрм А., Липпм а а Э., Пускар Ю., Изв. АН ЭССР, Хим. Геол., 17, № 4,427 (1968). 